\title{
Tunneling connective tissue graft sebagai prosedur perawatan resesi gusi kelas I Miller
}

\author{
Prajna Metta ${ }^{1 *}$, Aldilla Miranda ${ }^{1}$, Nunung Rusminah ${ }^{1}$, Heni Puspitadewi', \\ ${ }^{1 * D e p a r t e m e n ~ P e r i o d o n t i, ~ F a k u l t a s ~ K e d o k t e r a n ~ G i g i ~ U n i v e r s i t a s ~ P a d j a d j a r a n, ~ I n d o n e s i a ~}$ \\ *Korespondensi: prajna.metta@unpad.ac.id \\ Submisi: 27 Juli 2018; Penerimaan: 28 November 2020; Publikasi online: 31 Agustus 2020 \\ DOI: $10.24198 / \mathrm{jkg} . v 32 \mathrm{i} 1.18042$
}

\begin{abstract}
ABSTRAK
Pendahuluan: Resesi gusi pada regio anterior rahang atas seringkali menjadi perhatian dari segi estetik, bentuk dan fungsi. Resesi dapat terjadi pada satu atau beberapa gigi dan pada satu atau beberapa permukaan, sehingga menyebabkan kehilangan perlekatan dan terbukanya permukaan akar. Tujuan laporan kasus ini mempresentasikan keberhasilan perawatan resesi gusi kelas I Miller menggunakan teknik tunneling connective tissue graft. Laporan kasus: Pasien wanita, 37 tahun, datang dengan keluhan hipersensitifitas pada gigi depan dan belakang rahang atas serta gigi-gigi terasa lebih memanjang. Pemeriksaan klinis menunjukkan resesi gusi yang bervariasi sebesar 2-4 mm tanpa melibatkan mucogongival junction yang meluas dari gigi 15 sampai 25 . Terdapat tambalan glass ionomer pada daerah servikal gigi 22 sampai 24 . Hasil pengukuran lebar gusi berkeratin lebih dari $3 \mathrm{~mm}$. Diagnosa dari kasus ini adalah kelainan mucogingival multipel Kelas I Miller. Rencana perawatan yang akan dilakukan adalah prosedur tunneling connective tissue graft pada regio anterior labial rahang atas 22 sampai 24. Prosedur dilakukan dengan menutup bagian akar yang terbuka menggunakan connective tissue dari daerah palatal area premolar yang kemudian difiksasi dengan teknik jahitan anchorage. Perawatan ini menunjukkan hasil berupa penambahan ketebalan gusi berkeratin dan pengurangan sensitifitas akar tanpa adanya kekambuhan setelah enam bulan pasca bedah. Simpulan: Teknik tunneling dengan connective tissue graft dapat menjadi pilihan pada perawatan resesi gusi kelas I Miller dalam kasus ini berhasil menutup seluruh permukaan akar yang terbuka dan tidak terjadi relaps setelah enam bulan.
\end{abstract}

Kata kunci: Connective tissue graft, resesi, penutupan akar, tunneling..

\section{Tunnelling connective tissue graft as a treatment procedure for Miller Class I gingival recession}

\section{ABSTRACT}

Introduction: Gingival recession in the maxillary anterior region is often becoming aesthetical, shape, and functional concern. Recession can occur on one or several teeth and one or more surfaces, causing attachment loss and the root surface opening. This case report was aimed to present the successful treatment of Miller Class I gingival recession with the tunnelling connective tissue graft technique. Case report: Female patient, 37 years old, presented with complaints of hypersensitivity in the front and back of the maxilla and elongated-teeth sensation. Clinical examination showed gingival recession varying by 2-4 $\mathrm{mm}$ without involving the mucogingival junction extending from teeth 15 to 25 . A glass ionomer filling was performed in the cervical area of teeth 22 to 24 . The measurement result was keratinised gingival width of more than $3 \mathrm{~mm}$. The case diagnosis was multiple Miller Class I mucogingival abnormalities. The treatment plan performed was the tunnelling connective tissue graft procedure in the maxillary anterior labial region 22 to 24 . The procedure was performed by covering the exposed root using the connective tissue from the palatal area of the premolar area, which was then fixed with an anchorage suture technique. This treatment increase in keratinised gingival thickness and reduction in root sensitivity without recurrence after six months after surgery. Conclusion: Tunneling connective tissue graft can become an option in the treatment of Miller Class I gingival recession. In this case, it succeeded in covering the entire exposed root surface and does not relapse after six months.

Keywords: Connective tissue graft, recession, root coverage, tunneling. 


\section{PENDAHULUAN}

Selama bertahun-tahun, beberapa teknik bedah telah diperkenalkan untuk mengoreksi defek resesi gusi di labial karena dampaknya pada estetika dan hipersensitifitas dentin. ${ }^{1}$ Resesi gusi merupakan pergeseran margin gusi kearah apikal dari cementoenamel junction. Keadaan ini sering terjadi dan prevalensinya meningkat seiring dengan pertambahan usia. ${ }^{2,3}$ Berdasarkan populasi di berbagai negara di dunia, prevalensi kasus resesi gusi berkisar dari 30 hingga $100 \% .{ }^{4}$ Resesi lebih banyak terjadi pada pria dibandingkan wanita dengan perbandingan $3: 2 .^{3}$

Resesi dapat terjadi pada satu atau beberapa gigi maupun permukaan, sehingga menyebabkan kehilangan perlekatan dan terbukanya permukaan akar. Resesi ditandai dengan hilangnya jaringan ikat periodontal, sekaligus dengan sementum dan tulang alveolar. Hal tersebut dapat disebabkan oleh kebersihan mulut yang buruk, tarikan frenum, dehisensi tulang, restorasi yang tidak adekuat, malposisi gigi, dan kalkulus subgusi. .,6,7 $^{2}$ Resesi dapat timbul tanpa disertai gejala dan dapat menimbulkan rasa linu dari akar yang terbuka, kecemasan pasien akan kemungkinan giginya yang tanggal, estetik yang buruk dan karies pada permukaan akar. Akar yang terbuka menyebabkan berkurangnya tampilan estetik, hipersensitifitas dentin, dan berkurangnya kemampuan untuk menjaga kebersihan rongga mulut. ${ }^{5,8}$

Penatalaksanaan defek resesi pada gusi harus berdasarkan pemeriksaan klinis dan memperhatikan faktor etiologi dan derajat keparahan. Hal pertama dalam prosedur penatalaksanaan resesi gusi adalah dengan menghilangkan faktor etiologi. Bedah plastik periodontal untuk penutupan akar dapat dilakukan apabila faktor estetik menjadi pertimbangan pasien namun harus memperhatikan indikasi perawatan. ${ }^{5}$

Belakangan ini, banyak penulis menyarankan teknik tunneling dengan aplikasi connective tissue graft pada bedah penutupan akar. ${ }^{1,6,7}$ Seiring dengan meningkatnya permintaan estetis pasien, prosedur bedah dengan mempertahankan integritas papila sangat diperlukan. Raetze ${ }^{7}$ merupakan yang pertama sekali menggunakan teknik flap envelope untuk menutupi resesi gusi. Raetze ${ }^{7}$ melakukan flap partial thickness "envelope" untuk menempatkan connective tissue graft. Kemudian,
Allen $^{7}$ memodifikasi teknik ini dengan melakukan partial thickness supraperiosteal envelope untuk merawat beberapa gigi yang mengalami resesi. Dengan teknik ini, Allen melakukan insisi dibawah papila untuk menggerakkan flap ke koronal. Zabelegui, dkk. ${ }^{7}$ kemudian menamakan teknik ini "tunnel". Zuhr, dkk. ${ }^{7}$ memperkenalkan pendekatan microsurgical dengan menciptakan alat baru. Aroca, $\mathrm{dkk}^{8}$ memperkenalkan teknik "coronally advanced modified tunnel techinique" yang terdiri dari elevasi flap full thickness untuk memisahkan seluruh papila interproksimal dari tulang dan menempatkan penjahitan anchorage dengan menempatkan komposit pada titik kontak gigi untuk mecegah flap bergerak ke apikal. ${ }^{7,8}$

Perawatan resesi gusi dengan teknik tunneling menjadi lebih populer karena sifatnya yang lebih konservatif dan meningkatkan estetik. ${ }^{7}$ Elevasi flap tanpa melibatkan jaringan papila dan tanpa insisi vertikal berkontribusi pada meningkatnya suplai darah dan mempercepat proses penyembuhan. Selain itu, dengan menghindari dilakukannya insisi yang terlihat pada permukaan jaringan dapat meningkatkan estetis karena menurunkan resiko terbentuknya bekas luka paska bedah. ${ }^{7,9}$

Tujuan laporan kasus ini mempresentasikan keberhasilan perawatan resesi gusi kelas I Miller menggunakan teknik tunneling connective tissue graft.

\section{LAPORAN KASUS}

Seorang wanita 37 tahun datang ke Klinik Periodonsia, Rumah Sakit Gigi dan Mulut Universitas Padjadjaran, Bandung, Indonesia, dengan keluhan hipersensitifitas pada gigi depan dan belakang rahang atas serta gigi-gigi terasa lebih memanjang. Pemeriksaan klinis menunjukkan resesi gusi yang bervariasi sebesar 2-4 $\mathrm{mm}$ tanpa melibatkan mucogingival junction yang meluas dari gigi 15 sampai 25. Terdapat tambalan glass ionomer pada daerah servikal gigi 22 sampai 24 (Gambar 1A-D).

Lebar gusi berkeratin sebesar lebih dari $3 \mathrm{~mm}$. Diagnosis kasus ini adalah kelainan mucogingiva multipel Kelas I Miller karena defek resesi tidak melebihi batas mucogingival junction. Rencana perawatan sebelum dilakukan pembedahan, yaitu tindakan skeling, root planing, 
dan instruksi menjaga kebersihan mulut diberikan kepada pasien. Nilai indeks plak minimal dan tidak ditemukan inflamasi gusi pada pasien ini. Tambalan glass ionomer pada regio 22-24 juga dibuang menggunakan bur diamond untuk menyiapkan dentin yang sehat sebagai tempat perlekatan baru dari gusi. Pembedahan dilakukan dalam 2 kali tindakan yaitu pada regio 1 dan regio 2. Dalam laporan kasus ini, akan dibahas prosedur dengan tunneling connective tissue graft pada regio 22-24. Pasien telah menandatangani formulir persetujuan untuk publikasi laporan kasus ini.

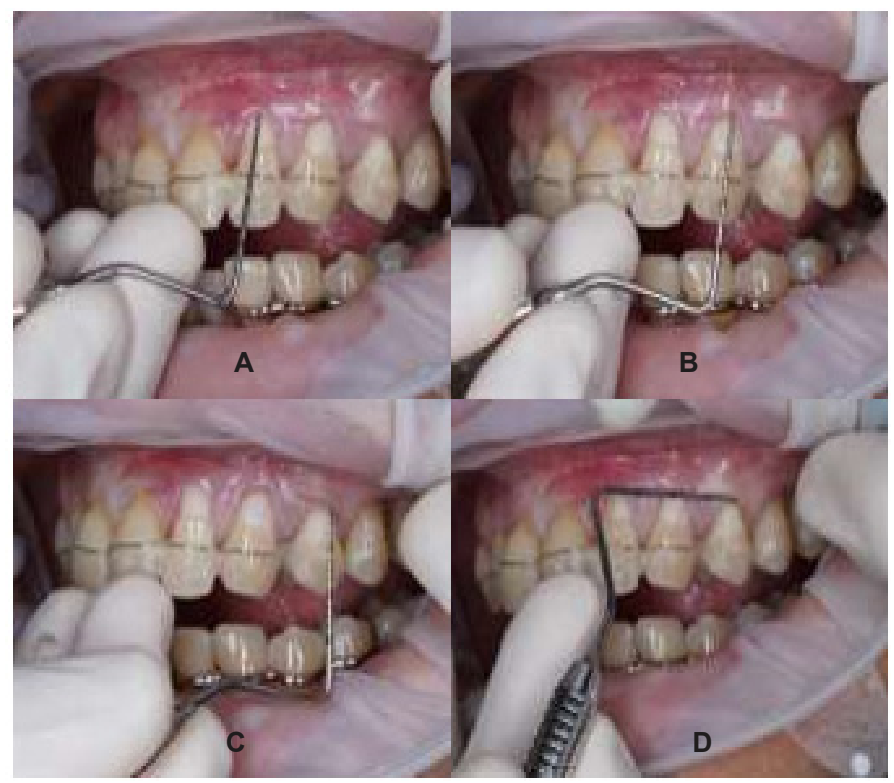

Gambar 1. Keadaan klinis pra operasi pada regio 22-24: A Pengukuran panjang resesi pada gigi 22; B. Pengukuran panjang resesi pada gigi 23; C. Pengukuran panjang resesi pada gigi 24; D. Pengukuran lebar daerah gusi yang akan dilakukan tunneling.(Sumber: Dokumentasi pribadi)

\section{Persiapan daerah resipien}

Setelah dilakukan anestesi lokal, prosedur tunneling dimulai dengan insisi sulkular pada margin gusi dari 22 sampai 24, untuk memperoleh akses yang adekuat pada area resesi. Tunnel subperiosteal dibuat dengan memasukkan periosteal elevator diantara periosteum dan tulang melalui akses insisi sulkular. Perluasan tunnel subperiosteal dilakukan sampai interproksimal di bawah setiap papila interdental tanpa memotong papilla. Tunnel tersebut diperluas sampai 1-2 gigi dari daerah resesi untuk memfasilitasi reposisi koronal gusi (Gambar 2A). Akar yang terbuka kemudian dihaluskan dan diratakan serta diaplikasikan bahan tetracycline HCL 500 mg yang dilarutkan dalam $10 \mathrm{ml} \mathrm{NaCl}$ dengan cotton pellet selama 3 menit sebelum prosedur pencangkokan gusi (Gambar 2B-C).

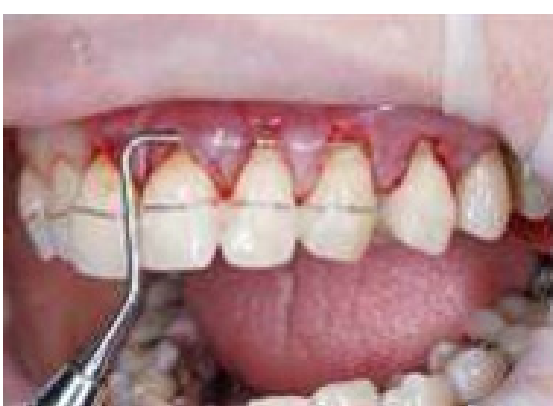

A

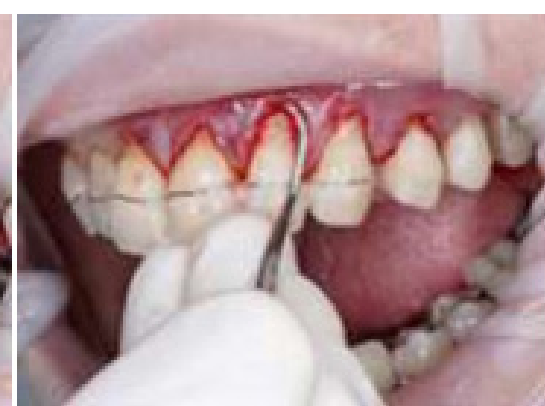

B

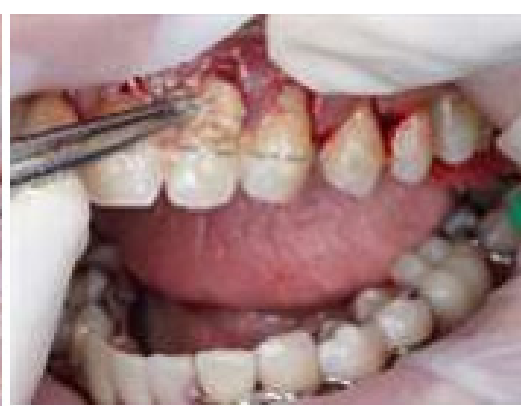

C

Gambar 2. (A) Pembuatan subperiosteal tunnel; (B) prosedur root planing; (C) prosedur root conditioning dengan tetracycline HCL. (Sumber:Dokumentasi pribadi)

\section{Pengambilan jaringan donor}

Jaringan donor untuk prosedur penutupan akar harus diukur secara akurat. Alumunium foil dapat digunakan untuk mengukur kebutuhan graft 
(Gambar 3A-B). Setelah tindakan anestesi lokal, dilakukan satu insisi pada daerah palatal, 3 $\mathrm{mm}$ dari daerah margin gusi gigi premolar 24 sampai 26. Insisi dibuat tegak lurus dengan jaringan palatal sampai ke tulang dalam arah horizontal. Panjang insisi ditentukan oleh dimensi jaringan donor yang diperlukan untuk pencangkokan. Setelah full thickness flap dibuat, jaringan diangkat setinggi 1-2 $\mathrm{mm}$ dengan hati-hati menggunakan elevator kecil untuk memudahkan diseksi flap.

Setelah flap diangkat, dilakukan diseksi partial thickness flap menggunakan pisau \#15c. Periosteum dipertahankan dan tetap menutupi permukaan tulang bersamaan dengan sebagian jaringan ikat gusi (Gambar 4A-C). Jaringan gusi setebal kurang lebih $1,5 \mathrm{~mm}$ diambil dari daerah donor, dan flap pada daerah palatal kemudian dijahit (Gambar 5A-C). Graft jaringan ikat kemudian disisipkan secara hati-hati ke dalam tunnel subperiosteal yang telah dipersiapkan menggunakan benang nylon 6-0 dan direposisikan dibawah margin gusi setiap gigi (Gambar 6AB). Graft dan komplek mucogingival kemudian direposisi ke arah koronal dan distabilisasi pada posisi yang baru dengan teknik penjahitan anchorage (Gambar 6C). Simpul jahitan diletakkan pada mahkota setiap gigi dan distabilisasi dengan bahan tambal komposit (Gambar 6D-F). Periodontal pack diaplikasikan pada seluruh daerah operasi untuk mengurangi retensi plak. Pasien diresepkan analgesik dan antibiotik serta diinstruksikan untuk menjaga kebersihan mulutnya. Jahitan dilepas setelah 10 hari dan kontrol setelah 6 bulan menunjukkan keberhasilan dalam penutupan akar sebesar $100 \%$. Tidak ada lagi keluhan terhadap hipersensitifitas akar dan masalah estetik. Pasien menyetujui kasusnya untuk dipublikasikan dengan menandatangani informed consent.

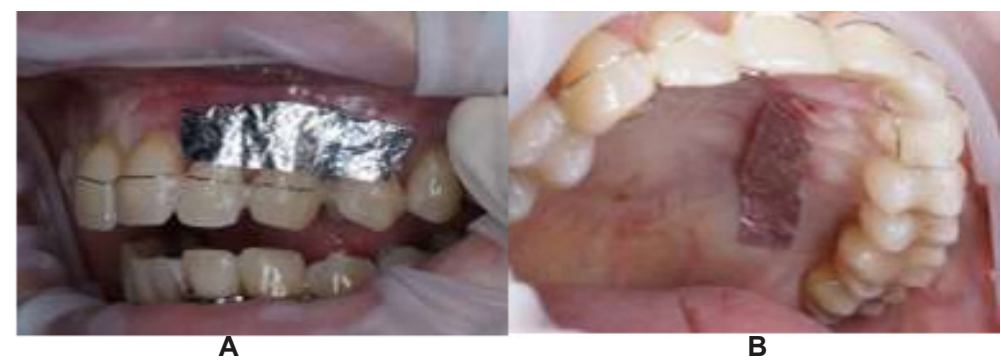

Gambar 3. (A) Alumunium foil digunakan untuk mengukur kebutuhan jaringan graft pada daerah resesi; (B) Alumunium foil kemudian dipidahkan ke bagian palatal sebagai ukuran untuk pengambilan jaringan donor. (Sumber: Dokumentasi pribadi)
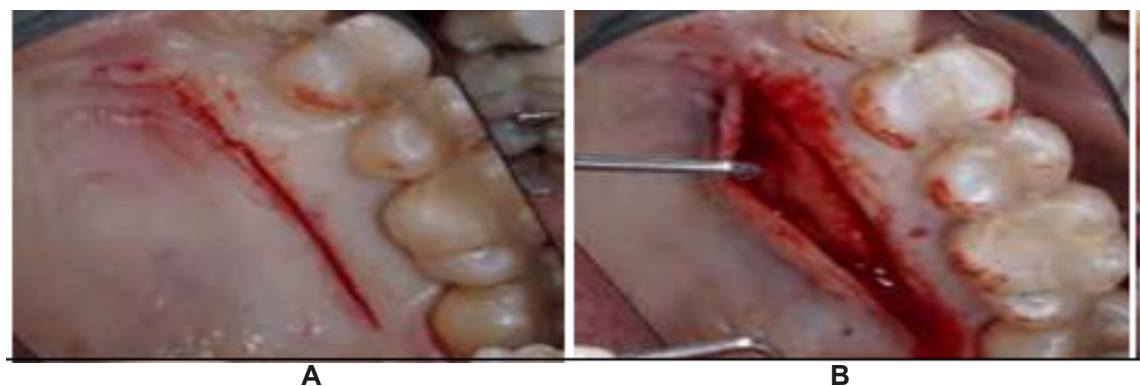

B

Gambar 4. (A) Insisi horizontal pada bagian palatal regio 24 sampai 26; (B) dan (C) partial thickness flap untuk mengambil jaringan subconnective tissue graft. (Sumber: Dokumentasi pribadi)

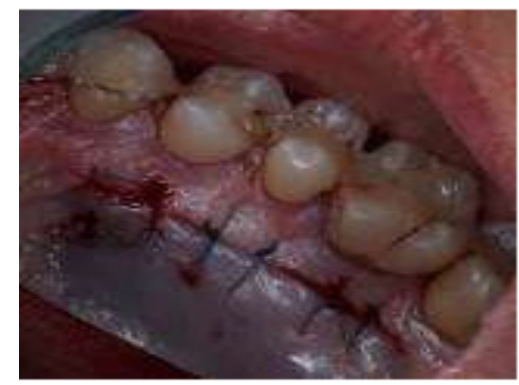

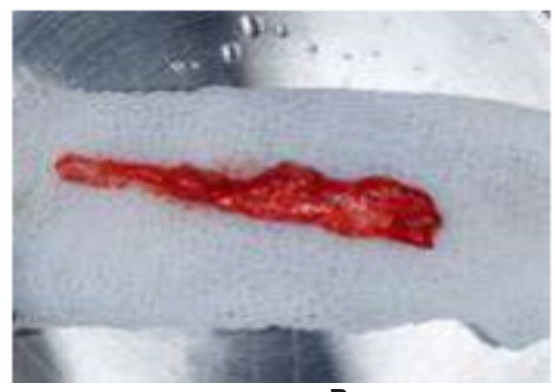

B

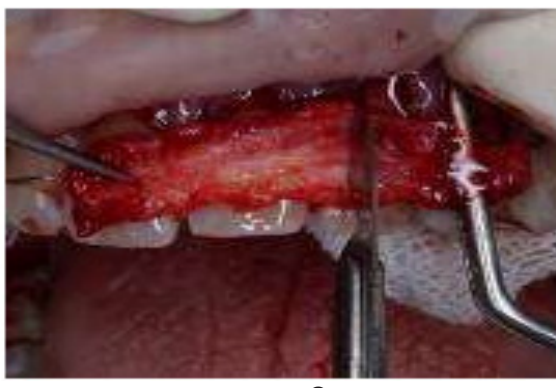

Gambar 5. (A) Hasil penjahitan bagian palatal; (B) Hasil pengambilan graft ditempatkan pada kassa steril yang dibasahi larutan saline steril; (C) Graft yang telah diambil dicocokkan dengan daerah resipien. (Sumber: Dokumentasi pribadi) 


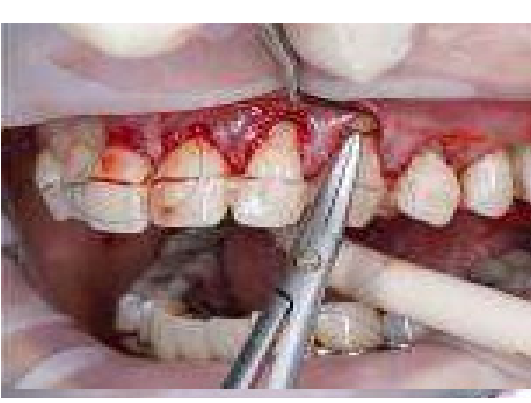

A

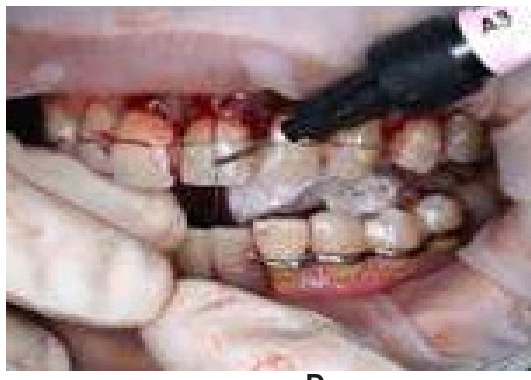

D

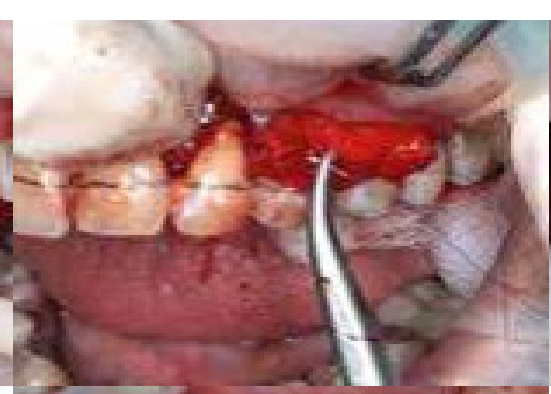

B

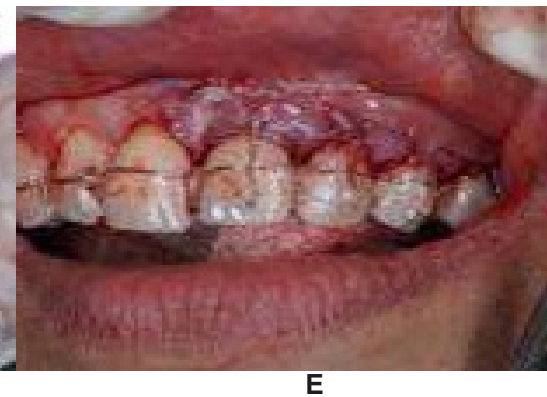

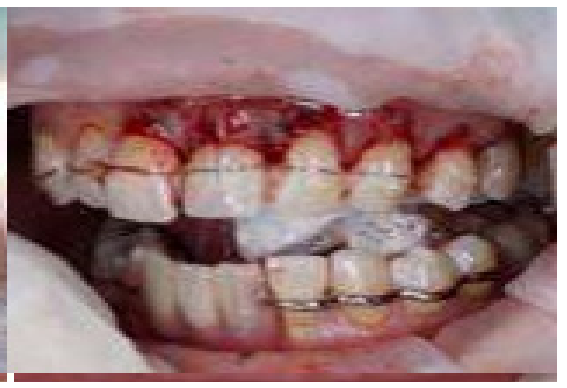

C

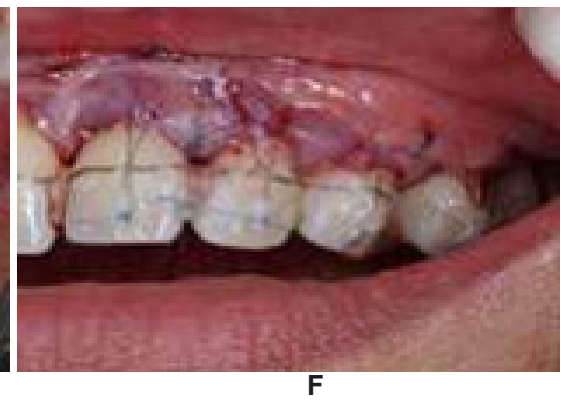

Gambar 6. (A) Benang nylon disisipkan melalui tunnel yang telah dibuat untuk membantu menarik (B) Graft dari sisi yang berlawanan ke bawah tunnel yang telah dipersiapkan. (C) Jahitan anchorage dilakukan dan (D) difiksasi di koronal setiap gigi dengan flowable composite. (E) Satu jahitan horizontal dibuat pada daerah mucogingival junction diatas graft untuk memfiksasi graft agar tidak bergerak ke arah apikal. (F) Hasil penjahitan anchorage. (Sumber: Dokumentasi pribadi)

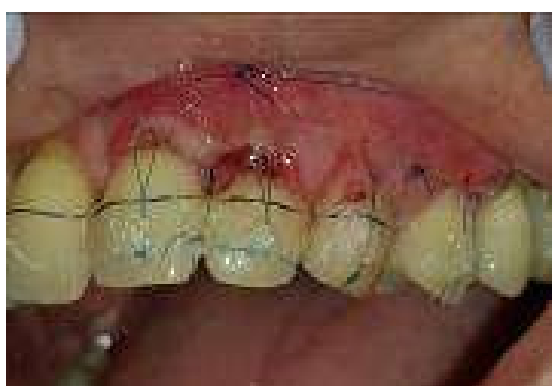

A

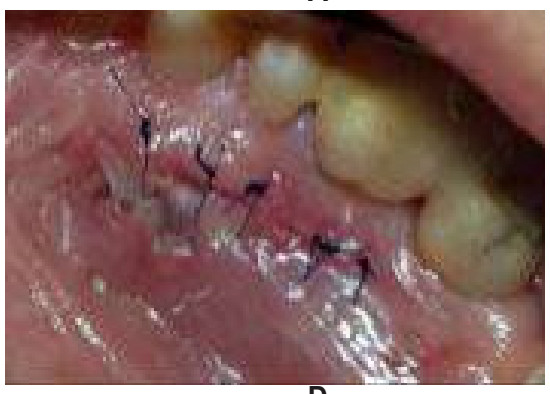

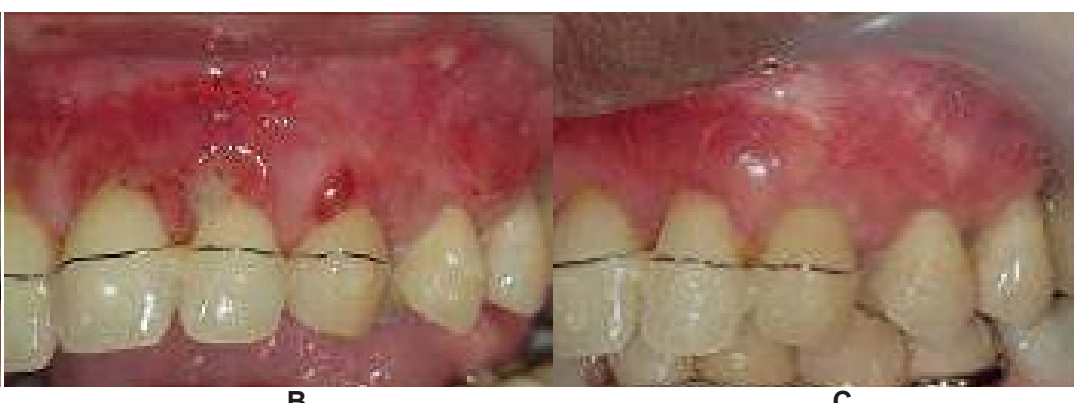

B

C

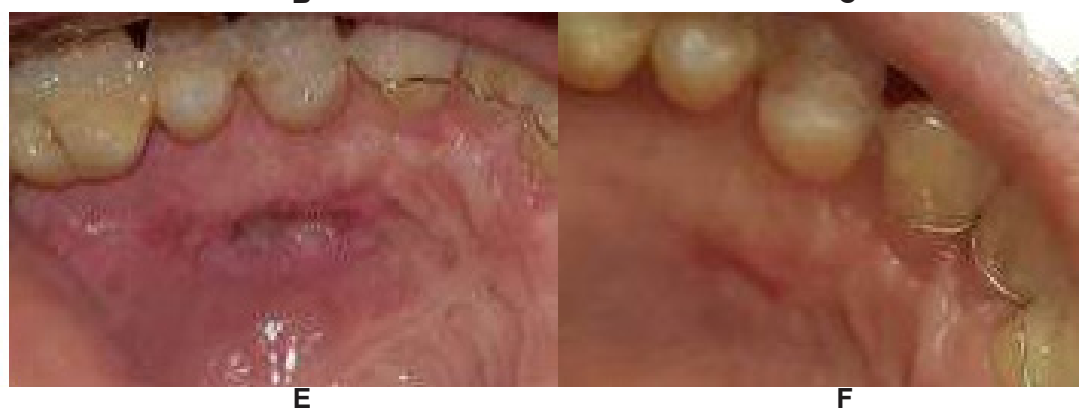

Gambar 7. (A,D) Kontrol 1 minggu pasca bedah; (B,E) Kontrol 10 hari pasca bedah dan setelah jahitan dilepas; (C,F) Kontrol 1 bulan pasca bedah. (Sumber: Dokumentasi pribadi)

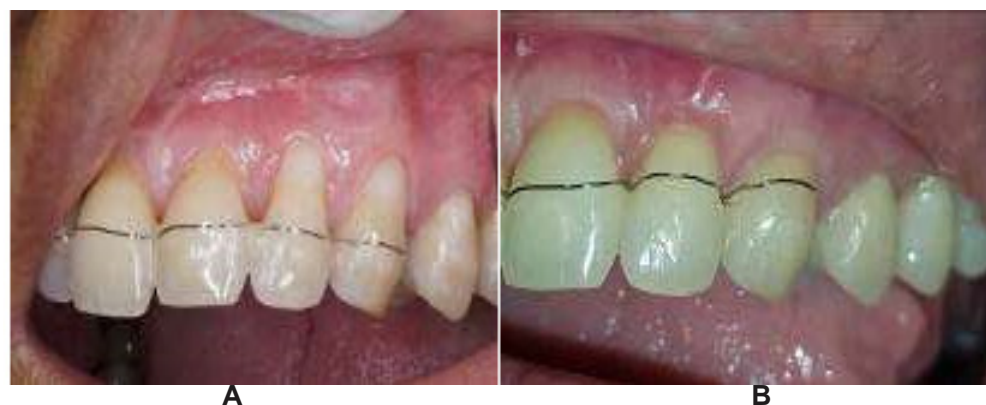

Gambar 8. (A) Gambaran klinis pra operasi dan (B) gambaran klinis saat kontrol 6 bulan pasca bedah. (Sumber: Dokumentasi pribadi) 


\section{PEMBAHASAN}

Keberhasilan penutupan akar adalah bagian penting dalam terapi periodontal. Banyak prosedur pembedahan yang dilakukan untuk mendapatkan hasil penutupan akar yang baik. Namun demikian, hasil yang kurang memuaskan dapat juga terjadi. Penyebabnya dapat karena seleksi kasus yang tidak tepat, pemilihan teknik bedah yang tidak tepat, preparasi akar yang inadekuat, kurangnya ketinggian tulang interdental dan jaringan lunak, tindakan bedah yang kurang baik, kurangnya suplai darah dari jaringan sekitar karena preparasi daerah resipien yang inadekuat dan penetrasi flap. ${ }^{10}$

Terdapat 4 teknik dasar penutupan akar: (1) pedicle grafts, (2) free gusil grafts, (3) connective tissue grafts, dan (4) membrane barrier guided tissue regeneration. Seluruh metode tersebut sering digunakan serta memiliki keuntungan dan kesulitannya masing-masing, juga tergantung dari pengalaman operator. Connective tissue graft adalah suatu prosedur bilaminer yang dirancang untuk memaksimalkan suplai darah supraperiosteal dan gusil ke graft jaringan. Graft diletakkan diatas daerah resesi sedangkan nutrisi dan revaskularisasi didapat dari daerah resipien, papila interdental dan flap yang menutupi graft. ${ }^{11}$

Prosedur tunneling tissue graft dipilih pada kasus ini dengan pertimbangan kurangnya gusi berkeratin pada daerah resesi. Teknik tunnel dirancang secara spesifik untuk resesi multipel yang luas yang sering ditemukan pada maksila dimana penutupan akar paling sulit didapat. Penggunaan teknik ini memperlihatkan hasil penutupan akar yang memuaskan. Teknik ini tidak saja dapat mempertahankan ketinggian papilla diantara dua defek mucogingival, tetapi juga membantu mempertahankan suplai darah yang adekuat untuk graft, memberikan adaptasi graft ke daerah resipien yang baik dan memberikan hasil estetik yang tinggi serta meningkatkan ketebalan gusi berkeratin. ${ }^{10}$

Teknik tunneling lebih unggul daripada teknik lain yang umum digunakan misalnya coronally advanced flap (CAF) karena pada teknik bedah CAF diperlukan insisi pada permukaan jaringan gusi dan papila interdental papila yang terbentuk pasca bedah CAF merupakan titik paling lemah dalam stabilisasi flap. Beberapa pengalaman dengan teknik bedah CAF menunjukkan bahwa ketika insisi dilakukan pada papila, sangat sulit untuk mencapai proses penyembuhan dengan primary intention. Pada awal masa penyembuhan, beban mekanis dan aktivitas mikrobiologis paling tinggi terjadi pada daerah interproksimal sehingga resiko penyembuhan dengan secondary intention pada jaringan papila sangat mungkin terjadi. Hal ini dapat menyebabkan terbentuknya bekas luka yang mengakibatkan berkurangnya kualitas jaringan dan menganggu estetika paska bedah. Penyebab lainnya adalah sulitnya untuk melakukan de-epitalisasi secara sempurna pada jaringan interproksimal yang penting untuk menyediakan tempat bagi jaringan yang akan diposisikan ke koronal, dan pada waktu bersamaan, harus tetap menjaga volume jaringan papila. ${ }^{9}$

Teknik tunneling terbukti sangat efektif dalam perawatan resesi gusi dengan rata-rata penutupan akar (mean root coverage) $82,8 \%$ untuk resesi tunggal dan $87,9 \%$ pada resesi multipel, serta penutupan akar seluruhnya (complete root coverage) sebesar $47,2 \%$ untuk resesi tunggal dan $57,5 \%$ untuk resesi multipel. Tingginya hasil penutupan akar pada resesi multipel daripada resesi tunggal dikarenakan bentuk flap yang lebih besar pada perawatan resesi multipel sehingga mobilitas dan penjahitan flap ke koronal lebih mudah dicapai. ${ }^{7,12}$ Teknik ini lebih diindikasikan pada rahang maksila dan kasus resesi gusi kelas I dan II Miller. De Sanctis dan Clementini menjelaskan lokasi gigi sangat berpengaruh terhadap keberhasilan perawatan. Faktor-faktor seperti tarikan otot yang tinggi dan vestibulum rendah, yang banyak dijumpai pada rahang mandibula, memiliki peran penting dalam hasil perawatan. ${ }^{13}$

Teknik tunneling memiliki beberapa kekurangan antara lain teknik ini memerlukan waktu yang lama dan ketelitian dalam preparasi tunnel. Selain itu, teknik ini juga menunjukkan tingkat morbiditas pasien yang tinggi dalam hal pembengkakan paska bedah dan hematoma, karena diperlukannya perluasan elevasi flap yang lebih ke lateral (mesial/distal) dibandingkan dengan teknik bedah lainnya. Kemudian, teknik ini tidak dapat digunakan dalam kasus resesi gusi tunggal dengan kedalaman lebih dari $3 \mathrm{~mm}$ karena mobilitas flap ke koronal yang terbatas sehingga dapat menyebabkan kemungkinan graft yang tidak tertutupi seluruhnya dan mengakibatkan graft nekrosis. Oleh karena itu, dalam kasus resesi 
gusi tunggal dengan kedalaman lebih dari $3 \mathrm{~mm}$, teknik bedah dengan insisi vertikal tidak dapat dihindarkan. ${ }^{9,14}$

Hal yang perlu diperhatikan dalam teknik tunneling connective tissue graft adalah diseksi subperiosteal yang teliti untuk mengurangi tegangan pada margin gusi saat reposisi ke koronal dan disaat yang bersamaan menjaga integritas anatomi dari papila interdental dengan menghindari refleksi atau flap pada papila. ${ }^{15}$ Faktor penting lainnya dalam keberhasilan prosedur penutupan akar adalah tindakan root conditioning. Aplikasi bahan asam pada permukaan akar telah terbukti dapat menghilangkan lapisan smear dan kontaminan. Demineralisasi permukaan akar dengan tetrasiklin dapat membuka tubuli dentin dan mengekspos kolagen dentin, sehingga menyediakan matriks yang mendukung migrasi dan proliferasi sel yang berperan pada penyembuhan jaringan periodontal dengan meningkatkan kemampuan perlekatan sel jaringan ikat pada permukaan akar. ${ }^{16,17,18}$ Teknik penjahitan anchorage menjadi suatu keuntungan karena dapat meminimalisasi pergerakan mikro (micromotion) pada daerah operasi akibat pergerakan fasial. ${ }^{15}$

\section{SIMPULAN}

Teknik tunneling dengan connective tissue graft dapat menjadi pilihan pada perawatan resesi gusi kelas I Miller dalam kasus ini berhasil menutup seluruh permukaan akar yang terbuka dan tidak terjadi relaps setelah enam bulan.

\section{DAFTAR PUSTAKA}

1. Gobbato L, Nart J, Bressan E, Mazzocco F, Paniz G, Lops D. Patient morbidity and root coverage outcomes after the application of a subepithelial connective tissue graft in combination with a coronally advanced flap or via a tunneling technique: a randomized controlled clinical trial. Clin Oral Investig. 2016; 20(8) :2191-2202. DOI: 10.1007/s00784-0161721-7.

2. Baker P. Gusil Recession-Causes and Management. Prim Dent J. 2020; 8(4): 40-7. DOI: $10.1308 / 205016820828463843$.

3. Mythri S, Arunkumar SM, Hegde S, Rajesh SK, Munaz M, Ashwin D. Etiology and occurrence of gingival recession - An epidemiological study. J Indian Soc Periodontol. 2015; 19(6): 671-5. DOI: 10.4103/0972-124X.156881.

4. Merijohn GK. Management and prevention of gusil recession. Periodontol 2000. 2016; 71(1): 228-42. DOI: 10.1111/prd.12115

5. Stefanini M, Marzadori M, Aroca S, Felice P, Sangiorgi M, Zucchelli G. Decision making in root-coverage procedures for the esthetic outcome. Periodontol 2000. 2018; 77(1): 5464. DOI: 10.1111/prd.12205.

6. Moka LR, Boyapati R, Mutthineni RB, Putcha MS, Gunturu KR, Nagubandi KK. Comparision of coronally advanced and semilunar coronally repositioned flap for the treatment of gusil recession. J Clin Diagnostic Res. 2014; 8(1): 4-8. DOI: 10.7860/JCDR/2014/8928.4428

7. Tavelli L, Barootchi S, Nguyen TVN, Tattan M, Ravidà A, Wang HL. Efficacy of tunnel technique in the treatment of localized and multiple gusil recessions: A systematic review and meta-analysis. J Periodontol. 2018; 89(1): 1075-90. DOI: 10.1002/JPER.18-0066

8. Aroca $\mathrm{S}$, Molnár $\mathrm{B}$, Windisch $\mathrm{P}$, Gera I, Salvi GE, Nikolidakis D, et al. Treatment of multiple adjacent Miller class $\mathrm{i}$ and II gusil recessions with a Modified Coronally Advanced Tunnel (MCAT) technique and a collagen matrix or palatal connective tissue graft: A randomized, controlled clinical trial. J Clin Periodontol. 2013; 40(1): 713-20. DOI: 10.1111/jcpe.12112.

9. Zuhr O, Rebele SF, Cheung SL, Hürzeler MB. Surgery without papilla incision: tunneling flap procedures in plastic periodontal and implant surgery. Periodontol 2000. 2018; 77(1): 12349. DOI: $10.1111 /$ prd.12214

10. Dani S, Dhage A, Gundannavar G. The pouch and tunnel technique for management of multiple gusil recession defects. J Indian Soc Periodontol. 2014;18:774. DOI: 10.4103/0972124X.147431.

11. Tavelli L, Ravidà A, Lin GH, Del Amo FS, Tattan M, Wang HL. Comparison between Subepithelial Connective Tissue Graft and De-epithelialized Gingival Graft: A systematic review and a meta-analysis. J Int Acad Periodontol. 2019; 1;21(2): 82-96.

12. Rebele SF, Zuhr O, Schneider D, Jung RE, Hürzeler MB. Tunnel technique with connective tissue graft versus coronally advanced flap with 
enamel matrix derivative for root coverage: A RCT using 3D digital measuring methods. Part II. Volumetric studies on healing dynamics and gusil dimensions. J Clin Periodontol 2014;41(6):593-603. DOI: 10.1111/jcpe.12254.

13. De Sanctis M, Clementini M. Flap approaches in plastic periodontal and implant surgery: Critical elements in design and execution. J Clin Periodontol. 2014; 41(1): 108-22. DOI: 10.1111/jcpe.12189.

14. Zuhr O, Rebele SF, Schneider D, Jung RE, Hürzeler MB. Tunnel technique with connective tissue graft versus coronally advanced flap with enamel matrix derivative for root coverage: A RCT using 3D digital measuring methods. Part I. Clinical and patient-centred outcomes. J Clin Periodontol. 2014; 41(6): 582-92. DOI: 10.1111/jcpe.12178.

15. Chatterjee A, Sharma E, Gundanavar G, Subbaiah S. Treatment of multiple gusil recessions with vista technique: A case series.
J Indian Soc Periodontol. 2015; 19(1): 232-5. DOI: 10.4103/0972-124X.145836.

16. Pazmiño VFC, Rodas MAR, Cáceres CDB, Duarte GGR, Azuaga MVC, de Paula BL, Caliente EA, Soares S, Silveira EMV. Clinical Comparison of the Subepithelial Connective Tissue versus Platelet-Rich Fibrin for the Multiple Gingival Recession Coverage on Anterior Teeth Using the Tunneling Technique. Case Rep Dent. 2017;2017:4949710. DOI: 10.1155/2017/4949710.

17. Nanda T, Jain S, Kaur H, Kapoor D, Nanda S, Jain R. Root conditioning in periodontologyRevisited. J Nat Sci Biol Med. 2014; 5(1): $356-$ 8. DOI: $10.4103 / 0976-9668.136183$.

18. Mukherji A, Bhusari P, Parwani $S$, Chitnis P. Evaluation of citric acid and tetracycline hydrochloride as root conditioners on instrumented periodontally diseased root surfaces- A comparative SEM study. Int J Clin Dent. 2013; 6(4): 367-82. 